УДК 343.851

DOI https://doi.org/10.32849/2663-5313/2020.5.47

Микола Семенишин,

канд. юрид. наук, докторант

Донецького юридичного інституту Міністерства внутрішніх справ України

\title{
КРИМІНАЛЬНО-ПРАВОВА ХАРАКТЕРИСТИКА АГРЕСИВНОЇ КОРИСЛИВО-НАСИЛЬНИЦЬКОЇ ЗЛОЧИННОСТІ
}

У статті на підставі аналізу кримінально-правових та кримінологічних ознак бандитизму, викрадення людини та вимагання встановлено, шо в иих злочинах агресія виконує роль фактору поведінки суб'єкта, який проявляє себе на всіх етапах скоєння злочину. У механізмі злочинної діяльності вона є інструментом досягнення корисливої мети злочину, одним із компонентів мотивачї, а також складовим елементом системи способу злочину. На иій основі обгрунтовано доводиться кримінологічна однорідність агресивних корисливо-насильнииьких посягань та можливість їх інтеграиї̈ в рамках системної злочинної діяльності.

3 метою забезпечення прикладного характеру дослідження нами виділено декілька складів злочину, які планується піддати науковому аналізу. Саме иі злочини розглядаються як сигнальні у категорії агресивних корисливо-насильницьких посягань. Навіть на рівні кримінально-правових ознак між ними є значна доля подібності, зокрема в об'єктах злочинного посягання та в об'єктивній стороні, зокрема елементів складів злочинів, передбачених статтями 257 («Бандитизм»), 146 («Незаконне позбавлення волі або викрадення людини») та 189 («Вимагання») КК Украӥни.

Кримінально-правова характеристика вказаних злочинів являє собою законодавчо закріплену в нормах КК України інформацію про ознаки структурних елементів складу відповідних злочинів. Незважаючи на те, що основними об'єктами щих злочинів є різні категорї̈ суспільних відносин, додаткові об'єкти злочинних посягань (життя, здоров'я, особиста недоторканність) здебільшого співпадають. Злочинне діяння виражене у формі активних за змістом дій: напад як раптовий вступ злочиниів у контакт із потерпілим, що може закінчитися заподіянням шкоди його здоров'ю та життю, прямо або опосередковано перевтілюється в інші форми посягання, зокрема в захоплення та вилучення жертви викрадення людини або пред'явлення вимог у разі вимагання. Виконання об'єктивної сторони проаналізованих злочинів завжди супроводжується насильством (фізичним або психічним), що з урахуванням встановленого нами раніше зв'язку між насильством та агресією свідчить також на користь однорідності цих злочинів (при цьому насильство є законодавчо визнаною формою інструментальної агресіі).

У виборі оптимального напряму дослідження відповідного правового феномена не можна обмежуватися елементами його складу, необхідно знати його кримінологічно значимі ознаки, що стосуються часу, місия, обстановки, способів і механізму скоєння злочинів, а також встановити наявність між ними певних залежностей корелячійних зв'язків. Але че вже - завдання іншої наукової категорї кримінологічної характеристики злочинів певної категорї.

Ключові слова: корисливо-насильницька злочинність, агресія, кримінально-правова характеристика, запобігання

Постановка проблеми та її актуальність. Серед негативних явищ у сфері захисту конституційних прав і свобод громадян України останнім часом привертають увагу проблеми забезпечення особистої недоторканності та створення належних, а головне, безпечних умов життєдіяльності людей. Особливе занепокоєння викликає не лише той факт, що в Україні протягом досить тривалого часу спостерігається стійка тенденція до існування доволі високого рівня агресивної корисливо-насильницької злочинності, до категорії якої належать украй небезпечні форми злочинних посягань на власність та особу власника, але й посилення жорстокості та цинізму під час скоєння інших злочинів, їх інтеграції в рамках цілісної системної злочинної діяльності. Нормою стає поєднання таких злочинів, як бандитизм, викрадення людини та вимагання в діяльності організованих злочинних угруповань.

Аналіз досліджень і публікацій. Проблеми запобігання корисливо-насильницьким злочинам не раз ставали предметом наукового дослідження. Загальнотеоретичну базу дослідження становлять праці вчених у галузі кримінології, а саме: Ю. Антоняна, О. Бандурки, В. Батиргарєєвої, 
В. Бесчастного, О. Бобильова, М. Валуйської, В. Голіни,Б. Головкіна, О. Джужі, А. Закалюка, А. Зелінського, Л. Левицької, О. Литвинова, В. Лунєєва, О. Ходимчук, О. Храмцова, В. Шакуна, Н. Яницької та інших. Але в цих роботах майже не надавалася кримінально-правова характеристика саме агресивної корисливо-насильницької злочинності.

Виклад основного матеріалу. Правовий зміст злочинності як соціального явища може бути охарактеризовано насамперед у кримінально-правовому аспекті, що, своєю чергою, служить базою для розробки інших характеристик, у тому числі й кримінологічної. Практичне значення цих характеристик визначається тим, що вони служать працівникам правоохоронних органів як інформаційні моделі, застосування яких забезпечує вирішення конкретних завдань розслідування, причому кримінально-правова характеристика «відіграє роль стрижня всього комплексу характеристик і надає йому системних властивостей, а іiі зміст зумовлює більшою чи меншою мірою зміст усіх інших характеристик» $[1$, с. 14].

Щодо змісту кримінально-правової характеристики, то слід зазначити, що у кримінальному праві відсутня домінуюча позиція щодо іï складників. У більшості наукових робіт кримінально-правова характеристика злочину включає в себе висвітлення об'єктивних та суб'єктивних ознак складу конкретного злочину. Але останнім часом представниками «харківської юридичної школи» (В. Борисов, О. Пащенко) пропонується включити до складу цієї характеристики такі елементи, як: 1) соціальна зумовленість встановлення та збереження кримінальної відповідальності за певний вид злочинів; 2) суспільна небезпечність певного виду злочинів; 3) протиправність діяння та іï місце в системі нормативного визначення заборони відповідного виду суспільно небезпечної поведінки; 4) склад певного виду злочинів; 5) суспільно небезпечні наслідки та інші обставини вчинення злочинів, що перебувають поза межами складу певного виду злочинів, але притаманні ї вчиненню; 6) особа злочинця. Остання позиція є обгрунтованою. Але, на нашу думку, вищеперераховані елементи в більшості підходять до кримінально-правового аналізу конкретного злочину, ніж до характеристики [2, c. $180-190]$.

Загалом доцільність висвітлення кримінально-правової характеристики під час дослідження методичних проблем запобігання злочинам визнає більшість учених-кримінологів, адже положення кри- мінального права детермінують загальну спрямованість методичних рекомендацій служити точному з'ясуванню таких питань: 1) чи є в дії або бездіяльності конкретного суб'єкта склад злочину і який саме; 2) чи підлягає такий суб'єкт кримінальній відповідальності. Від кримінально-правової характеристики злочину значною мірою залежить не тільки характер завдань, що виникають у процесі запобігання йому, але і порядок їх вирішення.

Відповідно до закону (ст. 2 КК України) підставою кримінальної відповідальності вважається вчинення діяння, що містить усі ознаки складу злочину, передбаченого Кримінальним кодексом [3]. У правовій літературі під складом злочину розуміється сукупність встановлених у кримінальному законі юридичних ознак (об'єктивних i суб'єктивних), що визначають вчинене суспільно небезпечне діяння як злочинне [4, c. 503].

Об'єктивні ознаки характеризують об'єкт та об'єктивну сторону злочину, суб'єктивні - суб'єкт і суб'єктивну сторону. Такі ознаки разом з відповідними фактичними обставинами діяння утворюють конкретний злочин. Сукупність характеристик кожного iз зазначених елементів становить зміст кримінально-правової характеристики окремого виду злочину. Значення цієї характеристики для правозастосовної практики визначається насамперед тим, що вона забезпечує розмежування подібних, близьких за складом злочинів, створюючи умови для їх правильної кримінально-правової кваліфікації.

3 метою забезпечення прикладного характеру дослідження нами виділено декілька складів злочину, які планується піддати науковому аналізу. Одночасно зазначимо, що саме ці злочини нами розглядаються як сигнальні у категорії агресивних корисливо-насильницьких посягань. Ми припускаємо, що навіть на рівні кримінально-правових ознак між ними є значна доля подібності, зокрема в об'єктах злочинного посягання та в об'єктивній стороні. Тож розглянемо окремі елементи складів злочинів, передбачених статтями 257 («Бандитизм»), 146 («Незаконне позбавлення волі або викрадення людини») та 189 («Вимагання») КК України.

Об'єкт злочину має виключно вагоме практичне значення щодо аналізу такої категорії злочинів, адже саме об'єкт злочину значною мірою впливає на визначення самого поняття «агресивні корисливо-насильницькі злочини».

Проблема об'єкта злочину досліджувалась у роботах багатьох учених $[5 ; 6]$, 
проте останнім часом у літературі з'явилось декілька нових, цікавих у науковому плані позицій. Наприклад, колективом авторів під керівництвом Н. Кузнєцової обгрунтовується думка, що «під об'єктом злочину слід розуміти певні соціально значущі цінності, інтереси, на які посягає злочинне діяння, спричиняючи шкоду, та котрі охороняються кримінальним законом» [7, с. 202]. Г. Новосьолов дотримується іншої точки зору. Він вважає, що об'єктом будь-якого злочину в одних випадках виступають окремі фізичні особи, у других - певного роду сукупності осіб, що мають або не мають статусу юридичної особи, у третіх - соціум (суспільство) загалом» $[8$, с. 60].

Слід зазначити, що і теоретично, і практично правильним $є$ загальне розуміння об'єкта злочину як суспільного відношення, що охороняється кримінальним законом. Таке розуміння об'єкта випливає із ч. 1 ст. 11 КК України, відповідно до якої злочином є передбачене кримінальним законом суспільно небезпечне винне діяння (дія або бездіяльність), вчинене суб'єктом злочину (людиною) [3]. Втім, слід зазначити, що не всі суспільні відносини можуть виступати як об'єкт. Зазначимо, що об'єктом можуть виступати лише ті відносини, «на які посягає злочин, спричиняючи певну шкоду».

Згідно зі статтею 1 КК України, кримінально-правовому захисту підлягають права і свободи людини і громадянина, власність, суспільний порядок і суспільна безпека, навколишне середовище, конституційний лад України, мир і безпека всього людства [3]. Характер суспільних відносин, на які посягає злочин, зумовлює ступінь його суспільної небезпеки: чим ціннішим є для суспільства об'єкт злочину, тим більшою є тяжкість скоєного злочину. Отже, об'єктом будь-якого злочину є суспільні відносини, що охороняються кримінальним законом.

Як один 3 елементів суспільних відносин, що охороняються кримінальним законом, законодавець прямо називає людину [9, с. 91]. Людина - поняття багатомірне та багатоаспектне, яке відображує сукупність iï біологічних, психологічних та соціальних властивостей.

Фахівці у сфері кримінального права розрізнюють загальний, родовий, безпосередній, додатковий і факультативний об'єкти злочинного посягання [10, с. 104, 118, 127-128]. Для характеристики агресивних корисливо-насильницьких злочинів вагомого значення набуває аналіз основних і додаткових об'єктів злочинного посягання.

Об'єктом бандитизму є громадська безпека (у зв'язку з чим, власне, ст. 257 КК Укра- їни потрапила до Розділу IX «Злочини проти громадської безпеки»). Громадська безпека це сукупність суспільних відносин, що забезпечують безпечне існування і свободу законної діяльності державних та громадських підприємств, установ, організацій та окремих громадян. Отже, основним об'єктом бандитизму є система суспільних відносин щодо безпечних умов життєдіяльності. Додатковими об'єктами можуть виступати окремі групи суспільних відносин або конкретні суспільні відносини (наприклад, групи відносин права власності або забезпечення особистої недоторканності) [11, с. 635].

Основним об'єктом викрадення людини виступає свобода людини, іï особиста недоторканність. При цьому свобода являє собою «життя, існування без залежності, можливість поводитися на свій розсуд, невимушеність»; можливість діяти без перешкод і заборон, здійснювати вільний вибір. Недоторканність припускає «гарантію від будьяких посягань з боку кого-небудь; недоторканний - це такий, який не можна псувати, знищувати, паплюжити через значимість, важливість, або той, що охороняється законом» [12, с. 167]. Отже, свобода людини має на увазі їі особисту недоторканність, що $€$ iï складовою та невід’ємною частиною і має гарантуватися у визначених межах суспільством та державою.

Безпосередній об'єкт викрадення людини - їі свобода - виступає як єдиний об'єкт дуже рідко. Проведене нами дослідження показало, що в 78\% випадків до викраденого застосовувалося фізичне насильство, а у $86 \%$ - мотивом викрадення людини була користь. Отже, додатковими об'єктами цього злочину нерідко виступають честь і гідність, здоров'я і безпека людини, право власності.

Основним об'єктом вимагання є право власності, яке являє собою специфічну сполуку соціального явища та економічної категорії. Вона утворена тріадою фактичних суспільних відносин володіння, користування та розпорядження благами, які належать власнику на законних підставах. Додатковими об'єктами злочинного посягання у разі вимагання є особиста недоторканність людини, їі безпека, свобода, життя, здоров'я, честь, гідність тощо [13, с. 144].

Другим елементом складу злочину є його об’єктивна сторона. Об'єктивна сторона злочину - це опис конкретних дій, що становлять зміст норми права, яка розглядає ці дії як суспільно небезпечне діяння. Змістом норми права охоплюються: злочинне діяння, злочинні наслідки і причинний зв'язок між ними [9, с. 42]. Іншими елементами об'єктивної 
сторони складу злочину є спосіб злочину, обстановка, час і місце скоєння злочину.

Основним елементом об’єктивної сторони злочину є діяння, яке характеризується насамперед способом дії або бездіяльності. M. Панов, здійснивши грунтовне кримінально-правове дослідження способів злочинів, розглядав їх (в узагальненому вигляді) як порядок, метод, послідовність рухів та прийомів, що застосовуються особою під час вчинення навмисних або необережних злочинів, які супроводжуються вибірковим використанням засобів скоєння злочинів [14, с. 8]. Розглядаючи способи скоєння злочинів як складові частини об'єктивної сторони злочину, що наповнені вольовим змістом та характеризуються як зовнішніми (суб'єктивними), так і внутрішніми (об'єктивними) ознаками, він критично висловлювався з приводу того, що окремі дослідники ототожнюють спосіб виключно зі злочинною дією [14, с. 7-9]. Вважаємо, що спосіб агресивних корисливонасильницьких злочинів зумовлений формами злочинного діяння, які містяться в нормі кримінального закону.

Бандитизм має місце у разі вчинення хоча б однієї з таких дій, як: організація озброєної банди; участь у такій банді; участь у нападі, вчинюваному бандою [3]. 3 точки зору предметної сфери дослідження особливий інтерес для нас являють бандитські напади на підприємства, установи й організації всіх форм власності або окремих осіб. Напад - це дії, спрямовані на досягнення злочинного результату за допомогою насильства над потерпілим або створення реальної загрози його застосування [15, с. 636].

Очевидно, що вища судова інстанція під нападом розуміла активні, агресивні дії банди, спрямовані на досягнення злочинного результату застосуванням насильства над потерпілим або створенням реальної загрози його негайного застосування, причому неважливо, чи використовувалась наявна у членів банди зброя, чи ні. 3 цим погоджуються й інші дослідники [16, с. 46-55]. Напад - це раптовий вступ злочинців у контакт із потерпілим, що може закінчитися заподіянням шкоди здоров'ю потерпілого аж до його смерті.

Викрадення людини охоплює протиправні навмисні дії, поєднані з таємним чи відкритим або шляхом введення в оману заволодінням (захопленням) живої людини, вилученням іiї $з$ природного мікросоціального середовища, переміщенням 3 місця постійного або тимчасового проживання 3 наступним утриманням всупереч ïi волі в іншому місці [13, с. 145]. Аналіз характеру захоплення та вилучення людини 3 мікро- соціального середовища іï існування дає змогу переконливо стверджувати про певну діяльнісну ідентичність цих понять раніше розглянутому поняттю «напад», адже ці дії $€$ активними та раптовими за змістом, здійснюються всупереч волі та бажанню потерпілого, у результаті чого людина втрачає здатність діяти за власним розсудом. Досить часто такі дії поєднуються з насильством.

Своєю чергою вимагання утворює такі дії, як пред'явлення майнових вимог та погроза застосування насильства, знищення або пошкодження майна, заподіяння іншої шкоди [11, с. 434]. 3 етимології розглянутих понять можна дійти важливого висновку: виконання об'єктивної сторони вимагання завжди супроводжується насильством (фізичним або психічним).

У разі фізичного насильства немає різниці, яку спричинено шкоду здоров'ю потерпілого: тілесні пошкодження, заподіяння смерті з необережності, побої або інше. Найпоширенішою формою фізичного насильства у разі вчинення вимагання виступае заподіяння тілесного ушкодження. Психічне насильство являє собою загрозу застосування фізичного насильства до самого потерпілого або його близьких та рідних, розголошення відомостей тощо. Психічне насильство повинне бути справжнім, а не уявним. Для встановлення факту застосування психічного насильства велике значення має характеристика сприйняття потерпілим самої загрози та іï реальності у співвідношенні та порівняно з фізичним насильством [17, с. $35-38]$.

Третім елементом складу злочину $€$ його суб'єкт. Суб'єктом викрадення людини є будь-яка осудна особа, яка досягла на момент вчинення діяння 16-літнього віку, а бандитизму та вимагання - 14-літнього. Такий вік встановлено з урахуванням суспільної небезпеки та поширеності розглянутих видів посягань серед молоді [11, с. 435].

Суб'єктивна сторона аналізованих злочинів характеризується виною у формі прямого умислу. Факультативними ознаками суб'єктивної сторони є мета та мотив злочинного діяння.

Мотив - спонукальна причина, те, що штовхає людину на виконання певних дій, те, заради чого вони відбуваються. Мета уявне передбачення результату діяльності, що направляє і регулює людську діяльність, зміст якої залежить від об'єктивної дійсності та реальних можливостей суб'єкта.

Цілі та мотиви являють собою тісно взаємозалежні поняття, що характеризують процеси, які відбуваються у свідомості людини. Їх встановлення має велике кримінальноправове і кримінологічне значення. 3 позицій 
кримінального права мотив іноді є кваліфікуючою ознакою, що впливає на міру відповідальності і покарання. 3 кримінологічної точки зору знання цілей і мотивів злочину дає змогу суттєво поповнити відомості про певну категорію злочинів.

Кримінальне законодавство передбачає склади злочинів, що мають зовнішню подібність до агресивних корисливо-насильницьких злочинів. Так, бандитизм, особливо відповідні напади, має багато спільного з розбоєм (ст. 187 КК України) та грабежем (ст. 186 КК України); викрадення людини - 3 незаконним позбавленням волі (ст. 146 КК України), захопленням заручників (ст. 147 КК України) та вимаганням (ст. 189 КК України), у зв'язку з чим виникає питання про розмежування зазначених складів злочинів.

Для відмежування бандитизму від розбою слід звернути увагу на такі обставини:

1) бандитизм, на відміну від групового розбою, характеризується більш високим рівнем організованості та стійкості злочинної групи. Групи, що скоюють розбійні напади, як правило, розпадаються після першого ж спільно скоєного злочину;

2) обов'язковою конструктивною ознакою банди є іï озброєність, однак нині не має значення, чи застосовувалась зброя під час нападу, чи ні. У складі розбою зброя виступає як кваліфікуюча ознака;

3) зброя у разі бандитизму розуміється вузько (лише вогнепальна, холодна і гладкоствольна), а у разі розбою - широко (інші предмети);

4) мотиви та діапазон цілей у разі бандитизму є набагато ширшими. Напади у разі розбою вчиняються лише 3 користі з метою заволодіння чужим майном. У разі бандитизму це не має суттєвого значення, адже дії злочинців можуть бути спрямовані і на вбивства, і на заволодіння майном, і на заподіяння школи здоров'ю тощо;

5) бандитизм є закінченим складом злочину вже 3 моменту організації банди без урахування того, чи вчинено нею хоча б один напад. Для наявності закінченого складу розбою має бути реальний напад з метою заволодіння майном. За наведеними критеріями бандитизм можна відмежувати і від інших складів злочинів, зокрема вимагання [11, с. $436 ; 15$, с. $637 ; 18$, с. $152-153 ; 19]$.

Що стосується відмежування викрадення людини від суміжних складів злочинів, то у правовій літературі найчастіше як на розмежувальну ознаку вказують на відсутність у разі незаконного позбавлення волі та викрадення людини мети впливу на третіх осіб для виконання ними певних вимог злочинців, що є характерним для захоплення заручни- ків. Проте відрізняти вказані злочини можна також за іншими ознаками, а саме:

1) за характером дій злочинців: особи, які вчиняють захоплення заручників, діють відкрито, нерідко вони прагнуть викликати суспільний резонанс, демонстративно виступаючи в засобах масової інформації, привертаючи до себе увагу; водночас особи, які вчиняють викрадення людини, діють таємно, вживаючи різних заходів щодо приховування слідів злочину;

2) під час захоплення заручників вимоги злочинців звернені до третіх осіб (представників влади, організацій, установ тощо). Викрадаючи людину, злочинці висувають вимоги безпосередньо викраденому або його близьким. Зазвичай вони стосуються одержання викупу, повернення боргу, відмовлення від боргу, виконання яких-небудь зобов’язань, передачі права на майно тощо;

3) захоплення заручників характеризується невизначеністю умислу злочинців, спрямованого на захоплення будь-якої людини. У разі ж викрадення намір злочинця спрямовано на викрадення конкретної людини;

4) у разі взяття заручників захоплення має місце завжди, але, як правило, без переміщення останніх. Це зумовлено тим, що злочинці спеціально обирають певне місце скоєння злочину й утримують заручників там до задоволення своїх вимог. Як ми зазначали, обов'язковою ознакою викрадення людини є не тільки захоплення, але і переміщення людини. За цією ознакою викрадення людини слід відрізняти також від розбійного нападу, бандитизму та вимагання [19, с. 174].

\section{Висновок}

Таким чином, кримінально-правова характеристика вказаних злочинів являє собою законодавчо закріплену в нормах КК України інформацію про ознаки структурних елементів складу відповідних злочинів. Незважаючи на те, що основними об'єктами цих злочинів є різні категорії суспільних відносин, додаткові об'єкти злочинних посягань (життя, здоров'я, особиста недоторканність) здебільшого співпадають. Злочинне діяння виражене у формі активних за змістом дій: напад, як раптовий вступ злочинців у контакт із потерпілим, що може закінчитися заподіянням шкоди його здоров'ю та життю, прямо або опосередковано перевтілюється в інші форми посягання, зокрема в захоплення та вилучення жертви, викрадення людини або пред'явлення вимог у разі вимагання. Виконання об'єктивної сторони проаналізованих злочинів завжди супроводжується насильством (фізичним або психічним), що 
з урахуванням встановленого нами раніше зв'язку між насильством та агресією свідчить також на користь однорідності цих злочинів (при цьому насильство є законодавчо визнаною формою інструментальної агресії).

І останнє, у виборі оптимального напряму дослідження відповідного правового феномена не можна обмежуватися елементами його складу, необхідно знати його кримінологічно значимі ознаки, що стосуються часу, місця, обстановки, способів і механізму скоєння злочинів, а також встановити наявність між ними певних залежностей - кореляційних зв'язків. Але це вже є завданням іншої наукової категорії - кримінологічної характеристики злочинів певної категорії.

\section{Список використаних джерел:}

1. Кудрявцев В.Н. Генезис преступления. Опыт криминологического моделирования : учебное пособие. Москва : Издат. дом «Форум», ИНФРА, 1998. 215 с.

2. Борисов В., Пащенко О. До питання про сутність кримінально-правової характеристики злочинів. Вісник академії правових наук України. 2005. № 3 (42). С. 180-190.

3. Кримінальний кодекс України : Закон від 05 квіт. 2001 р. № 2341-III. Верховна Рада України. URL: http://zakon5.rada.gov.ua/laws/ show/2341-14

4. Юридична енциклопедія: В 6 т. / ред. кол. Ю С. Шемшученко та ін. Київ: «Укр. енцикл.». Т. 5 : П-С. 2003. 736 c.

5. Учебник уголовного права. Общая часть / С.В. Бородин, В.Н. Кудрявцев, Н.Ф. Кузнецова и др. ; под ред. В.Н. Кудрявцева и А.В. Наумова. Москва : Изд-во Спарк, 1996. 432 с.

6. Таций В.Я. Объект и предмет преступления в советском уголовном праве. Харьков : Вища школа, 1988. 198 с

7. Курс уголовного права. Общая часть. T 1. Учение о преступлении / Г.Н. Борзенков, В.С. Комиссаров, Н.Е. Крынова и др. / под ред.
Н.Ф. Кузнецовой и И.М. Тяжковой. Москва : Изд-во ЗЕРЦАЛО, 1999. 512 с.

8. Новоселов Г.П. Учение об объекте преступления. Методологические аспекты. Москва : Изд-во НОРМА, 2001. 122 с

9. Кримінальне право України: Загальна частина : підручник / Ю.В. Александров, В.І. Антипов та ін. ; відп. ред. Я.Ю. Кондратьєв. Київ : Нац. акад. внутр. справ, 2002. 408 c.

10. Коржанський М.Й. Уголовне право України. Частина загальна : курс лекцій. Київ : Наукова думка, 1996. 336 с.

11. Науково-практичний коментар Кримінального кодексу України / за ред. М.I. Мельника, М.І. Хавронюка. 4-е вид., переробл. та допов. Київ : Юрид. думка, 2007. 1184 с.

12. Новий тлумачний словник української мови: у 3-х т. Київ : Аконіт, 2006. Т. II. 926 с.

13. Кримінальне право України: Особлива частина : підручник / М.І. Бажанов, Ю.В. Баулін, B.I. Борисов та ін. ; За ред. проф. М.І. Бажанова, В.В. Сташиса, В.Я. Тація. 2-е вид., перероб. і доп. Київ : Юрінком Інтер, 2005. 544 c.

14. Панов Н.И. Основные проблемы способа совершения преступления в советском уголовном праве : автореф. дис. ... докт. юрид. наук : 12.00.08. Харьков, 1987. 35 с.

15. Науково-практичний коментар Кримінального кодексу України / за заг. ред. О.М. Джужі А.В. Савченка, В.В. Чернєя. 2-ге вид., перероб. і допов. Київ : Юрінком Інтер, 2018. 1104 с.

16. Чорний Р.Л. Бандитизм за кримінальним правом України : монографія. Київ : ДП «Друкарня МВС України», 2007.224 с.

17. Иванова В.В. Преступное насилие : учебное пособие. Москва : Книжный мир, 2002. 95 с.

18. Вознюк А.А. Кримінально-правові ознаки організованих груп і злочинних організацій : монографія. Київ : Нац. акад. внутр. справ, 2015. $192 \mathrm{c}$.

19. Кузнецов В.В., Савченко А.В. Теорія кваліфікації злочинів: підручник. / за заг. ред. С.М. Моісєєва, О.М. Джужи. 2-е вид., переробл. Київ : КНТ, 2007. $300 \mathrm{c}$.

In the article, based on the analysis of criminal and criminological features of banditry, kidnapping and extortion, it is found that in these crimes aggression acts as a factor of behaviour of the subject, which manifests itself at all stages of the crime. In the mechanism of criminal activity, it is a tool to achieve the selfish purpose of crime, one of the components of motivation, as well as an integral element of the system of crime. On this basis, the criminological homogeneity of aggressive acts of self-aggression and the possibility of their integration within the framework of systemic criminal activity is substantiated.

In order to ensure the applied nature of the study, we have identified several crime scenes that are planned to undergo scientific analysis. These crimes are considered as signal in the category of aggressive acts of self-aggression. Even at the level of criminal signs between them there is a considerable share of similarities, in particular in the objects of criminal assault and in the objective side, in particular the elements of the crimes, provided for in Articles 257 ("Banditry"), 146 ("Unlawful imprisonment or abduction" human) and 189 ("extortion") of the Criminal Code of Ukraine.

The criminal-law characterization of these crimes is a statutory information in the norms of the Criminal Code of Ukraine on the features of the structural elements of the composition of the respective crimes. Although the main objects of these crimes are different categories of social relations, additional objects of criminal encroachment (life, health, personal integrity) for the most part coincide. Criminal activity is 
expressed in the form of active, meaningful actions: assault, as the sudden entry of criminals into contact with the victim, which may result in harm to his health and life, directly or indirectly translates into other forms of encroachment, in particular the capture and removal of the victim of kidnapping or making claims when requested. The objectivity of the crimes analyzed is always accompanied by violence (physical or mental), which given the previously established link between violence and aggression, also testifies to the homogeneity of these crimes (violence being a legally recognized form of instrumental aggression).

When choosing the right direction to study the relevant legal phenomenon can not be limited to the elements of its composition, it is necessary to know its criminologically significant features related to the time, place, situation, methods and mechanism of crime, as well as to establish the existence of some correlations between them. But this is already the task of another scientific category of criminological characteristics of crimes of a certain category.

Key words: selfish-violent crime, aggression, criminal law characteristics, prevention. 